\title{
Assessing the current practice of Auditing in Islamic Financial Institutions in Malaysia and Indonesia
}

\author{
Nawal Kasim, Zuraidah Mohd Sanusi, Tatik Mutamimah, and Sigit Handoyo
}

\begin{abstract}
Drastic development of Islamic financial institutions globally may lead to new expectations of and requirements for accountability, which in turn lead to new demands on the audit function of the institutions. The prohibition of interest and the aspiration of Muslims to make this prohibition a practical reality in their economies, has led to the establishment of a number of Islamic financial institutions around the world. The study examines the scope of the current practice of auditing in Islamic financial institutions using questionnaires survey in Malaysia and Indonesia. As Malaysia has taken drastic initiatives to become the global Islamic finance hub, and Indonesia having its own Shariah Audit manual for IFIs, it would be interesting to study on the development of these two countries in respect of the current scope of shariah audit practice. The findings record that the gap is wider for Indonesia which is in need of the four dimensions for Shariah audit tested in this study. The only gap that exists for Malaysia is in relation to the scope of Shariah auditing. This does not support the hypothesis that since Indonesia has a Shariah audit manual being in place in the country, at least they have a better guidance for the implementation of Shariah auditing. Majority of the respondents are in the opinion that more has to be done for Indonesia in the process of catching up with the development of Islamic finance in Malaysia in particular for this study, the auditing perspective.
\end{abstract}

Index Terms-Auditing, Islamic financial institutions (IFIs), Shariah audit, Malaysia, Indonesia.

\section{INTRODUCTION}

Recent accounting scandals, where companies prepared fraudulent financial statements, and auditors issued clean opinions on the fraudulent statements, have eroded the trust among participants in the financial markets. During the late 1990s, Sunbeam Corporation went into bankruptcy and in early 2002, Enron and Worldcom, two large corporations in the world collapsed losing billions of dollars. People have started to re-evaluate the level of trust they put on audit to provide assurance for investment and financial information, and the trend of solely depending on audit as the best source of credibility for such information may have now become defunct [1].

Despite all these tragedies, the growth of the Islamic banking and finance has developed enormously over the last few years. The Islamic financial institutions (IFIs) in particular, which are set up with different objectives and

Manuscript received May 20, 2013; revised July 23, 2013. This work was supported in part by the ARIHICoE research fund.

Nawal Kasim and Zuraidah Mohd Sanusi are with the Accounting Research Institute, Faculty of Accountancy, Universiti Teknologi MARA, Shah Alam, Malaysia (e-mail: nawal120@salam.uitm.edu.my).

Tatik Mutamimah and Sigit Handoyo are with Universitas Islam Indonesia, Yogyakarta, Indonesia. worldview, and are drastically growing in numbers worldwide, have not much choice but to depend on the current system for auditing even though the governance structure and the operations are different from the normal financial system. One clear approach of the IFIs is the introduction of Islamic products which should be in compliance with the Islamic law (Shariah) [2]. There have been positive steps by regulatory bodies in Malaysia in the current undertaking for the Islamic banking and finance industry to flourish further. The latest being the issuance of the Shariah Governance Framework by the Central Bank which is effective from 2011. However, the guidelines for Shariah auditing is viewed as insufficient taking into consideration that the Shariah compliance is the backbone of the operations of the IFIs [3]. The complexity and dynamism of the industry has increased the necessity of Shariah audit to be more comprehensive and integrated to provide strong assurance to stakeholders and other users on the Shariah compliance of the whole system and operations of the IFIs. AAOIFI, a standard setting body for IFIs, responsible for setting up accounting and auditing standards, has also come under criticisms by certain quarters on its methodology. Shahul [4] for instance called for an extensive overhaul for Islamic accounting if it were to endure for a long time. Kasim et al. (2009) expressed that lacking in the proper auditing practices in IFIs is a major problem facing the current Shariah auditing framework [5]. Indonesia, a neighboring country to Malaysia, with Muslim majority population, has also taken an initiative in producing a Shariah Audit Manual for its IFIs.

The objective of this study is to comparatively examine the extent of the current practice of Shariah auditing being implemented in IFIs in Malaysia and Indonesia, and to investigate if there is a gap between the two countries in terms of four perspectives; scope of audit, regulatory framework used qualification and independence of the Shariah auditors. As Malaysia has taken drastic initiatives to become the Islamic banking and finance hub specifically for South East Asia countries, and Indonesia having its own Shariah Audit manual for IFIs, it would be interesting to study on the development of these two countries in respect of the current Shariah audit practice.

\section{LITERATURE REVIEW}

The introduction of Islamic laws into Islamic financial institutions has resulted in great changes; especially in the way the institutions do their business. This has also affected the audit of these institutions. Accordingly, the normal audit objective has been changed to agree with the Islamic law even though the normal conventional auditing is unable to cater for the values of Shariah Islamiah [6]. According to 
Harahap, conventional auditing is based on a system which is value-free and does not take into consideration the moral and ethical values laid down by Islam.

The conventional approach to audit is incomplete as it pays little attention to the organizational and social context of auditing [7]. It is argued that the basic auditing model is flawed since it makes auditors financially dependent on companies. The Western secular model of ethics (reflected in the conventional accounting or auditing) generally propose a system of ethics divorced from religion [8]. Its capitalistic approach is unsuitable for the Islamic economic system, which, on the other hand, places high moral values, fairness and 'Maslahah of the Ummah' (for the benefits of Muslim society) as among its principles. Thus, according to Haneef [9], due to differences in the Islamic economic vision to those of Western economics, coupled with the epistemological and methodological framework in Islamic scholarship, the development of Islamic economic thought (and consequently policy prescriptions) differs. He then suggests that Islamic economics (including finance, banking or accounting) should be evaluated within its own framework and using its own criteria.

In the traditional conventional audits, an auditor is mainly concerned with verifying the accuracy of the recording of transactions in traditional financial accounting systems and with reviewing companies' financial statements. The scope of work is limited to being a technical expert, well versed in the mechanics of recording systems, dealing in quantitative data, and issuing a general report on the adherence or otherwise to established standards. A different picture should emerge for a shariah auditor. It should perhaps include an audit of a forward looking operating and financial review, with a commentary on the strategy, performance and quality of management [10]. Here the emphasis might well be on executing audits of managerial behavior, testing the accuracy of strategic accounting methods and checking the details of accounting for human resources as assets and liabilities rather than as operational costs. According to Khan [11], the scope of auditing in the Islamic framework is much larger than the traditional auditing; from the traditional concept of attest and authority, to reporting on various social and economic aspects of business organizations.

So far, Muslims in Islamic finance industry sector have employed a highly sophisticated understanding of transactions, based on a prescribed set of shariah-approved contracts, to further their financial ends. The principles articulated by the shariah for transacting business have long been the subject of study by Muslim legal and financial professionals [12]. Islamic law and its precepts for living are part of every Muslim's cultural and spiritual identity. Thus, regardless of where Muslims may live in the world today, it is a matter of considerable importance that they will be able to live their lives in accordance with their beliefs. The simple truth within the Islamic belief is that when the earth and everything in it belong to the Almighty, the relationship of humankind and the material world is that of a caretaker [13]. The Almighty allows humankind the use of the physical universe, hopefully for good and, in return, humankind agrees to be accountable for how the physical universe is used. This includes serious consideration of the business to be invested in and its policies, the products it produces, the services it provides, and the impact that these have on society and the environment.

As mentioned earlier, shariah auditing process is expected to be extensive, detailed and complex. Besides attestation of accounts, it could involve expressing an opinion on honesty, regularity, economy, efficiency or effectiveness, or reporting the incidence of fraud, mal-administration or managerial incompetence, or failure to observe procedures or attain goals. The scope of shariah auditing should be concerned with the realization of benefit to the people. Shariah auditors should therefore be alert on any mismanagement of IFIs that can cause loss to others such as to the financiers who have invested their funds, to the public who have the right to zakat payment, and also to the environment that should be kept in balance [14]. In conclusion, Islam imposes a dual-accountability concept, whereby a person is accountable for his actions in this world and he will be answerable to the Almighty in the hereafter.

For that reason, auditing in the Islamic perspective needs to address the social aspects of Islam and attempt to develop the necessary logistics of incorporating it in the financial statement audits of the Islamic institutions [15]. More importantly, true compliance and implementation of auditing involves adopting a mindset that influences all aspects of the audit [16]. From the shariah perspective, business conducted by Muslims must be responsible business [17]. IFIs in particular, must assure that the whole Islamic financial system is shariah compliant, thus a need to transform the traditional concept of attest and authority (as in conventional audit) to report on various social and economic aspects of business organization. In order to achieve the objective of shariah in particular the principle of social equity, the scope of auditing in the Islamic perspective should be wider as compared to the scope of conventional auditing.

The role of shariah auditors is as vital as any other segments in the governance structure of the IFIs, if not more. As with any other organizations, IFIs need to have some form of 'check and balance' on the matters related to shariah compliance of the organizations. The main argument is that an IFI would need a comprehensive scope of shariah audit to sustain itself and to remain significant in the eyes of the stakeholders and to ensure all activities of IFIs are in line with the organization's objectives. This study will explore the current scope shariah audit in IFIs in Malaysia and Indonesia. Although the status of shariah compliance audit is becoming a necessary part of IFIs' overall monitoring structure, and studies in this aspect are still lacking [18], this study is expected to contribute in terms of an added knowledge to the literature of auditing from the Islamic perspective. There is numerous literature produced pertaining to Islam and economics. Yet, none of them were able to make significant progress in creating an Islamic economy in any true sense. However, the $21^{\text {st }}$ century should see a more favorable climate as drastic growth of Islamic banking sector and Islamic capital markets are gaining wider acceptance. In addition to the academic value it has on this area, this should make the study a practical importance to those who have interest in IFIs regarding Islamic control mechanism approach. 
Driven by developments and ever-accelerating change in Islamic banking and capital markets, industries, and technology, a shariah auditor is expected to have a wider scope of responsibility to keep abreast with the developments. It is therefore the intrinsic purpose of this study to be of benefit to both the employer and the shariah/internal auditing profession to better understand the increased emphasis of the scope of work of a shariah auditor, to be in parallel with the scope of the shariah audit

\section{RESUlTS AND FindINGS}

Forty seven responses are from Indonesia while those from Malaysia are eighty five. In describing the Indonesian sample, majority of the respondents are the external auditors, who worked in the full-fledged Islamic Financial Institutions. Majority have the Shariah qualifications and working in the auditing and accounting field. Representing the Shariah auditors in Indonesia, their opinion on the current Islamic auditing concept is significantly different from the conventional audit practice thus making the objective of the research attainable and relevant. As for Malaysia, from 85 of the replied respondents, majority of them are from the management of the Islamic Financial Institutions. Apart from that most of them are from the full-fledged Islamic Financial Institutions who also have the Shariah qualifications but not having much experience in auditing or accounting field. Similar to the Indonesian responses, they are also giving the same opinion on the current Islamic auditing concept that should significantly be different from the conventional audit practice.

Further analysis of the study began with examining four sets of questions representing four elements to be tested towards their shariah compliance auditing practices; the scope, the regulatory framework used, the qualification and the independence of the shariah auditors. Going through the analysis of four different dimensions of the elements, the finding shows that there are significant correlations among the four elements. In the analysis of the Malaysian data, all the variables have strong correlations between one another. Almost all have around 0.75 . The variables have strong correlation if the $r-$ value is 0.5 to 1.0 . The result shows the highest correlation is between the two statements in the dimension of scope. They are 'The scope of the Shariah audit is restricted to financial statement audit' and 'The scope of Shariah audit is limited to compliance with rules and procedures only' at $r=0.767, p<0.01$. The $r$ value of this correlation is higher than 0.5 , therefore, it indicates that there is a strong positive correlation between these two statements. Thus this makes the element scope is very important in deciding the Shariah compliance element of auditing from the Islamic perspective for the Malaysian practitioners.

The other 3 dimensions are showing $r$ below 0.5 , indicating that they are not considered to be crucial for the Malaysian respondents. For them, the existing Shariah Governance framework produced by their Central Bank of Malaysia and are currently being used by the Islamic banks in Malaysia are already sufficient to be implemented from the perspective of the four dimensions except for the scope.

On the other hand, when analyzing the same data from the respondents from Indonesia, the $r$ value is even higher than those from the Malaysian data and the highest $r$ being 0.92 on the dimension of the regulatory framework used. The result indicates that Indonesian practitioners of Shariah auditing are in need of proper regulated framework to guide them to carry out Shariah compliance auditing. Surprisingly almost all of the other three dimensions are presenting $r$ above 0.5 . This may indicate that Indonesian practitioners are still looking for a properly in place Shariah audit guidelines in terms of the scope, the regulatory framework, the qualification and the independence of the Shariah auditors. This is an indication that the four dimensions should be available if implementation of Shariah Audit is to be realized. Hence the currently used Shariah Audit Manual is considered by the respondents insufficient.

The quantitative results above are triangulated using in-depth interviews with selected few from among the respondents to the questionnaires. Out of the twelve interviewees, only two are from Indonesia. Most interviewees agree with the idea of shariah auditing scope be extended into a wider scope other than shariah compliance of the products only. However, when they are asked on whether their organizations are ready or willing to extend the scope of shariah auditing into a wider dimension for instance social and environmental audit in the near future, all seem not to agree. Among the reasons given by the interviewees for not favoring into extending the scope of shariah audit are: shariah auditors should concentrate on the more important task at hand i.e. shariah compliance of products; lack of a complete set of framework which covers the comprehensive shariah auditing practices, what more the social and environmental audit; an external body should be looking into the matter, not them; costly; and lack of expertise.

Finally, the paper attempts to analyse the gap that exists between the two countries, as summarised in Fig. 1. Taking the total of 5 items representing the total number of issues with gaps (Malaysia=Dimension of "Scope" only while Indonesia=the four dimensions i.e. Scope, Regulatory framework, Qualification \& Independence), it is noted that $1 / 5$ or $20 \%$ of the total gap is the gap for the Malaysian Islamic finance scenario. The balance of $4 / 5$ or $80 \%$ is the composition of the gap for those of the Indonesians.

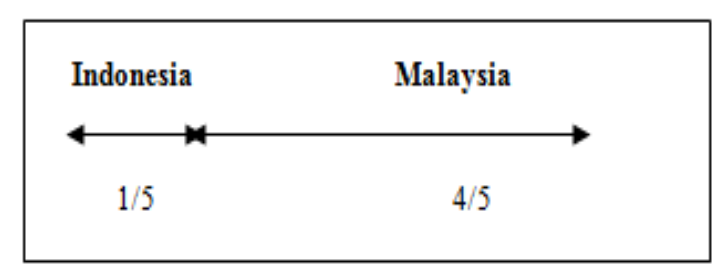

Fig. 1. A scale diagram of the gap analysis.

It can therefore be summarized that the gap is wider for Indonesia which is in need of the four dimensions for Shariah audit to be implemented. The only gap that exists for Malaysia is in relation to the scope of shariah auditing. This does not support the hypothesis that since Indonesia has a Shariah Audit Manual being in place in the country, at least they have a better guidance for the implementation of shariah auditing in the country.

To summarise the findings, it is worth noted that this 
research should be interpreted in light of certain limitations. The significant gap in the sizes of the sample respondents for both countries may indeed affect the generalization of the survey findings. However, this is considered adequate for the purpose of this research. Another issue of concern is that more should be interviewed so that a wider group of expertise are available to discuss specific aspects of shariah audit in detail.

\section{CONClusion}

In conclusion, it may be gathered that it is not an easy task to perform shariah auditing which cover a broader concept of Shariah Islamiah to meet its objectives under the conditions of the capitalistic profit-maximization mindset and competitive conventional financial system. This problem is further compounded by the decline of Islamic moral, social and economic values in Muslim countries including Malaysia and Indonesia, under the progressive pressure of colonization and cultural domination of the western world during the last few centuries [19]. This has contributed to a total disregard for Islamic socio-economic values by some quarters of IFIs.

As far as extending the scope of shariah audit to a broader sense to be in line with the objectives of the Islamic law, IFIs are facing with challenges from the well-established conventional financial system. Shariah auditors may face with immense challenges from the policy makers and top management who are progressive thinkers of diverse faiths and practices [20]. Above all, lacking in a comprehensive shariah audit framework and expertise add to the problem of implementation.

The interviews have provided insights into the factors that influence the gaps that exist between the expectation of the ideal shariah auditing and the current practice of shariah auditing in IFIs. Of particular important is the cooperation between the shariah people and the internal auditors is possible in making the successful implementation of the Sharuah auditing practices. If preserving status-quo of each other's positions is put aside for the sake of achieving the Maq'asid Ash-Shariah (objective of the Shariah Law) specifically for the socio-economic objective, this may enhance the potential of collaborating both qualifications for the sake of auditing in IFIs. The identification of the existing gap may help clarify the problem and stimulate thinking towards possible solutions in future research.

At present, the shariah auditing practice in IFIs is unregulated in its true sense, either in Indonesia, Malaysia or other parts of the world that practice Islamic banking and finance. With only a small portion of shariah audit being discussed in the shariah audit framework of the Central bank in Malaysia for instance, the need for a comprehensive framework of shariah auditing in IFIs is timely. At the moment, each IFI develops its own policies or at a minimum, an audit checklist. In the absence of generally accepted criteria of shariah auditing, this research finds that people who are directly or indirectly involved with shariah auditing in IFIs in Malaysia and Indonesia consider shariah auditing function is evolving and having a proper framework of shariah auditing would be part of their main agenda in future undertaking. It has a significant impact on their current shariah audit practice. It is reasonable to infer, therefore, that in addition to having a framework of shariah auditing in IFIs, shariah auditors also consider the framework to be of importance to them to preserve their competency and independence.

\section{REFERENCES}

[1] C. Humphrey, Debating Audit Expectations: Current Issues in Auditing, London: Paul Chapman Publishing Ltd., 2000.

[2] M. H. H. Besar, M. E. A. Sukor, N. A. Muthalib, and A. Y. Gunawa, "The practice of Shariah review as undertaken by Islamic banking sector in Malaysia," International Review of Business Research Papers, vol. 5, no. 1, pp. 294-306, 2009.

[3] A. G. Ismail and A. Tohirin, "Islamic law and finance," Humoanomics, vol. 26, no. 3, pp. 178-199, 2010.

[4] H. M. I. Shahul, "Nurtured by 'Kufr': The western philosophical assumptions underlying conventional (Anglo-American) accounting," International Journal of Islamic Financial Services, vol. 2, no. 2, pp. 19-37, 2002.

[5] N. Kasim, S. H. Ibrahim, and M. Sulaiman, "Shariah auditing in IFIs: Exploring the gap between the desired and the actual," Global Economy \& Finance Journal, vol. 2, no. 2, pp. 127-137, 2009.

[6] S. S. Harahap, Auditing dalam Perspektif Islam Auditing in the Islamic perspective, Pustaka Quantum, Jakarta, 2002.

[7] P. Sikka, S. Filling, and P. Liew, "The audit crunch: reforming auditing," Managerial Auditing Journal, vol. 24, no. 2, pp. 135-155, 2009.

[8] R. I. Beekun, "Balancing ethical responsibility among multiple organizational stakeholders: The Islamic perspective," Journal of Business Ethics, vol. 60, pp. 131-145, August 2005.

[9] M. A. M. Haneef, "Islam, the Islamic worldview, and Islamic economics," IIUM Journal of Economics \& Management, vol. 5, no. 1, pp. 39-65, 1997.

[10] A. Banaga, G. Ray, and C. Tomkins, "External audit and corporate governance in Islamic banks: A joint practitioner-academia research study," Avebury, Hants, England, 1994.

[11] M. A. Khan, "Al-Hisba and the Islamic economy," in Ibn Taymiya, Public Duties in Islam: The Institution of Hisba, Leicester, UK, 1981.

[12] D. Lorenzo and Y. Talal, "The religious foundations of Islamic finance in Islamic Finance: Innovations and Growth," Euromoney Books and AAOIFI, pp. 9-41, 2002.

[13] M. N. Siddiqui, Some Aspects of the Islamic Economy, Islamic Publications Ltd., Lahore, 1982.

[14] M. A. Khan, "Role of auditor in an Islamic economy," Journal of Research in Islamic Economics, 1985.

[15] M. A. Khan, "Role of supreme audit institutions in shaping the Islamic economy in the 21 st century," IIUM Journal of Economics and Management, vol. 9, no. 1, pp. 77-100, 2001.

[16] T. P. Houck, Why and How Audits Must Change, John Wiley \& Sons, Inc., Canada, 2003.

[17] N. Yusoff and N. M. Affandi, Islam and Business, Pelanduk Publications, Subang Jaya, 2003.

[18] K. L. Hood and R. Bucheery, "The interaction of financial and religious (Islamic) auditors with reference to the audit expectation gap in Bahrain," Accounting, Commerce \& Finance: The Islamic Perspective Journal, vol. 3, no.1-2, pp. 25-58, 1999.

[19] A. H. A. A. Sulayman, Towards Islamization of Disciplines, The International Institute of Islamic Thought, Herndon, Virginia, 1989.

[20] A. R. A. Rahman, "Shariah auditing for Islamic financial services: the needs and challenges," presented at the International Shariah Research academy for Islamic Finance (ISRA) Islamic Finance seminar, in Kuala Lumpur, November 2008.

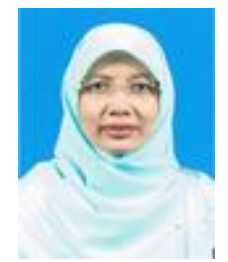

Nawal Kasim was born in Malaysia on June 14, 1961 She obtained her Ph.D. in Accounting from the International Islamic University Malaysia (IIUM), Kuala Lumpur, Malaysia in 2009, specializing in auditing from the Islamic perspective. She is an associate professor at the Faculty of Accountancy, University Teknologi MARA, Shah Alam, Malaysia. For the past three years, she has been attached as a research fellow to the Accounting Research Institute of Higher Ministry of Education (ARI HICoE), heading the institute's Islamic Accounting \& Mu'amalat Research Centre (IAMRC). She has written articles such as 
"Shariah auditing in Islamic Financial Institutions: Exploring the gap between the 'Desired' and the 'Actual'" in the Global Economy \& Finance Journal, Vol 2, No. 2, pp 127-137 (2009), "Crime Prevention in Islamic Institutions: Practices in Brunei Darussalam" in the Malaysian Accounting Review, Vol. 9, No. 2, pp 1-9 (2009) and "The influence of the concept of 'Taklif' to accountants in preventing fraudulent financial reporting and auditing" in the Malaysian Accounting Review, Vol. 9, No. 2, pp 71-83 (2010). Her research interest is in the areas of financial reporting, corporate governance and auditing.

Dr Kasim was involved as a working group member for International Shariah Research Academy (ISRA), a research wing of the Central Bank of
Malaysia and panel specialist (in the area of Islamic Accounting) for the Ministry of Higher Education to come up with a Standard Program for Islamic Finance \& Mu'amalat for Public/Private Universities. She was appointed as journal reviewers for Malaysian Accounting Review, Journal of Financial Reporting and Asian Academy of Management Journal of Accounting \& Finance. Currently she has been appointed as panel specialist for master of Muamalat and Shariah Audit syllabus review for Universiti Sains Islam Malaysia. She is also a member of the Malaysian Institute of Accountants. 